\title{
Bovine Coronavirus as the Causative Agent of Winter Dysentery: Serological Evidence
}

\author{
By S. Alenius, R. Niskanen, N. Juntti and B. Larsson \\ National Veterinary Institute and Department of Cattle and Sheep Diseases, \\ Swedish University of Agricultural Sciences, Uppsala, Sweden.
}

\begin{abstract}
Alenius, S., R. Niskanen, N. Juntti and B. Larsson: Bovine coronavirus as the causative agent of winter dysentery: Serological evidence. Acta vet. scand. 1991, 32, 163-170. - Sera from 9 dairy herds with epizootic enteritis (winter dysentery) were examined for antibodies to bovine coronavirus (BCV) and bovine virus diarrhoea virus (BVDV). Cows in 8 of the 9 herds seroconverted to BCV alone, while the animals in the ninth herd, which showed severe symptoms of the disease, seroconverted both to BCV and BVDV. The BCV antibodies, which were present in high titres 1 year postinfection, were transferred to the offspring via the colostrum and were then detectable in sera of calves until these were approximately 5 months old.

A serological survey of 549 Swedish heifers showed that $61 \%$ of the animals were reactors to $\mathrm{BCV}$. The prevalence of seroreactors to $\mathrm{BCV}$ was equally distributed over Sweden but was commonly either high or low in herds.

In conclusion, $\mathrm{BCV}$ is commonly detected in animals suffering from winter dysentery. A co-infection with BVDV appears to aggravate the disease.
\end{abstract}

bovine virus diarrhoea virus; indirect ELISA; antibodies.

\section{Introduction}

Winter dysentery or epizootic enteritis was first described by Hedström \& Isaksson (1951) in Swedish dairy herds. The disease still causes economic losses not only in Sweden but in many other countries as well. Winter dysentery is mainly characterized by severe diarrhoea and decreased milk production. The disease is highly contagious and occur predominantly in the adult cattle population. The mortality rate is low and an individual cow commonly recovers within a few days, although its milk production may not reach the preinfection level (for a review, see Fox 1980).

The causative agent of winter dysentery is still not fully known. Infection with bovine virus diarrhoea virus (BVDV) was initially described as a disease with a high morbidity rate, causing severe diarrhoea and coughing
(Olafson et al. 1946). However, Takahashi et al. (1983) found no significant increase in antibody titre to BVDV in cattle with winter dysentery. Campylobacter spp. have been isolated from outbreaks of winter dysentery and were considered as aetiological agents (Jones \& Little 1931). The rapid spread of the disease resembles more a virus infection. During the last decade bovine coronavirus (BCV) has been detected in faeces from cows with winter dysentery and has also been serologically related to this disease (Takahashi et al. 1980, Espinasse et al. 1982, Takahashi et al. 1983, Saif et al. 1988). Bovine coronavirus occurs with both enteric and respiratory strains but, apparently, as a single serotype (Reynolds et al. 1985, ElGhorr et al. 1989). This circumstance facilitates serodiagnosis of $\mathrm{BCV}$ infection in winter dysentery. 
The aims of the present study were $(a)$ to serologically relate BCV and BVDV to outbreaks of winter dysentery, $(b)$ to examine the titre of antibody to the agent during 1 year after infection and determine whether antibodies to $\mathrm{BCV}$ are transferred to the offspring via the colostrum, and (c) to examine the distribution of seroreactors to BCV in Sweden.

\section{Materials and methods}

\section{Dairy herds and blood samples}

During the winter and spring of $1986 / 87$, outbreaks of winter dysentery occurred in a large number of dairy herds in the central and northern parts of Sweden. Nine of the dairy herds (no. 1 to 9) with winter dysentery were serologically examined. All cows in these herds were affected and the main symptoms were watery to haemorrhagic diarrhoea and a decreased milk production. The cows in herds no. 3 to 9 also showed moderate to severe respiratory symptoms. Only a few animals succumbed to the disease or had to be emergency slaughtered. The body temperature was elevated in the few animals examined before they showed any symptoms, but was commonly normal during the phase of diarrhoea. Calves were usually asymptomatic but the calves in herd no. 2 had mild to severe diarrhoea and 1 calf succumbed to the disease.

Four to 7 cows per herd were bled in the acute phase of diarrhoea and 3 to 4 weeks later during the convalescence period. A third sample was collected from the animals approximately 1 year after the episode of diarrhoea. In addition, 6 calves born within 5 to 8 months after the disease in herd no. 1 were bled before they received colostrum and then at 4 to 6 days, and 1, 2, 3, 4, 5, 6 and 7 months of age.

To estimate the prevalence of seroreactors to $\mathrm{BCV}$, blood samples were collected from
549 heifers in 94 farms in 11 counties in different parts of Sweden. The herds and the cattle were selected by the local health veterinarians and the number of animals tested per herd varied between 1 and 14. From these 94 farms 58 herds with 5 to 14 tested animals were selected in order to evaluate the herd immunity. Herd selection was done by purposive and by convenience sampling. The blood samples were collected in vacutainer tubes and transported to the laboratory at ambient temperature. Serum was removed after centrifugation and stored at $-20^{\circ} \mathrm{C}$ until analysis.

\section{Virus and assays}

The BCV was represented by the cytopathic strain Munich W 270/83, and the BVDV by the Danish cytopathic strain Ug59 (Borgen 1963). An indirect enzyme-linked immunosorbent assay (ELISA) was developed for detection of antibodies to BCV. Initially, the results of theELISA were compared with those of a virus neutralization test (VNT). For detection of antibodies to BVDV, only ELISA has been used.

\section{Preparation of BCV antigen for ELISA}

The coating antigen was prepared as follows: Primary embryonic bovine lung (BL) cells were grown in Eagle's minimum essential medium (MEM) supplemented with $5 \%$ foetal calf serum (FCS) tested to be free from detectable IgG antibodies, as previously described by Juntti et al. (1987). The BL cells were grown at $37^{\circ} \mathrm{C}$ to confluence in $120-\mathrm{cm}^{2}$ bottles, the medium was removed and the cell monolayers were washed twice with Eagle's MEM (without FCS). Each bottle was inoculated with $5 \mathrm{ml}$ of the $\mathrm{BCV}$ suspension, diluted 1:100 and containing $100 \mathrm{TCID}_{50}$ per $0.1 \mathrm{ml}$. After absorption for $1 \mathrm{~h}$ at $37^{\circ} \mathrm{C}, 40 \mathrm{ml}$ of Eagle's MEM with $2 \%$ of IgG-free FCS were added. After 3 to 4 
days of incubation when 90 to $95 \%$ of the cells were destroyed, the bottles were frozen at $-70^{\circ} \mathrm{C}$. $\mathrm{BCV}$ antigen was prepared by thawing and freezing the virus suspension twice and then pelleting the virus and cell debris by centrifugation for $60 \mathrm{~min}$ at $100000 \mathrm{~g}$. The pellet from $400 \mathrm{ml}$ of the virus suspension was dissolved in $1 \mathrm{ml}$ of phosphate buffered saline (PBS) containing $1 \%$ of the detergent MEGA-10 and incubated for $1 \mathrm{~h}$ at room temperature. The lysate was sonicated for $30 \mathrm{sec}$ and clarified by low-speed centrifugation. The detergentsolubilized antigens were gel-filtered on a Sephadex G-50 column (Pharmacia Fine Chemicals, Uppsala, Sweden) to remove the detergent. The fltrate was used as BCV antigen for ELISA.

\section{Detection of antibodies to $B C V$}

In ELISA. The $\mathrm{BCV}$ antigen was diluted $1: 1000$ in coating buffer $(0.05 \mathrm{M}$ sodium carbonate buffer, pH 9.6, containing $0.1 \%$ $\mathrm{NaN}_{3}$ ) and $100 \mu \mathrm{l}$ was added per well in microtitre plates (Nunc, Denmark). The sera to be tested for presence of antibodies to BCV were diluted 1:10, 1:50, 1:250 and $1: 1250$ in PBS, containing $0.05 \%$ Tween (PBS-T). One hundred $\mu$ l of the serum dilutions was added to the BCV-coated wells and incubated for $1 \mathrm{~h}$ at $37^{\circ} \mathrm{C}$. After 3 washings with PBS-T, $100 \mu$ l of an optimum dilution of the horseradish peroxidase (HRP)-conjugated monoclonal antibody to bovine IgG was added per well and incubated for $1 \mathrm{~h}$ at $37^{\circ} \mathrm{C}$. The plates were then washed and a substrate solution $(0.1 \mathrm{mg}$ tetramethylbenzidine/ml, $0.1 \mathrm{M}$ sodium acetate and $0.05 \% \mathrm{H}_{2} \mathrm{O}_{2}$ ) was added in volumes of $200 \mu \mathrm{l}$ per well. After $10 \mathrm{~min}$ at room temperature, $50 \mu \mathrm{H}_{2} \mathrm{SO}_{4}$ was added to stop the reaction. The absorbance value at 450 $\mathrm{nm}$ was measured on a Titertec microplate reader (Flow Labs., Irvine, Scotland). A se- rum titre was estimated as the highest serum dilution giving an absorbance value above $0.10\left(0.10=\right.$ mean $A_{450} \pm 3$ S.D. of 46 sera negative for VNT antibodies to $\mathrm{BCV}$ ).

In VNT. Sera, preheated for $30 \mathrm{~min}$ at $56^{\circ} \mathrm{C}$ were diluted by 2 -fold dilution steps from $1: 4$ to $1: 256$. Each dilution was mixed with an equal volume of the virus suspension containing $100 \mathrm{TCID}_{50}$ per $0.1 \mathrm{ml}$.

Following incubation for $60 \mathrm{~min}$ at $20^{\circ} \mathrm{C}$, $0.2 \mathrm{ml}$ of the serum-virus mixture was inoculated into each of 2 tube cultures of $\mathrm{BL}$ cells. The cultures were checked for cytopathic effect (CPE) and final readings were made 3 to 5 days after inoculation when in the control tubes the monolayers showed complete degeneration. The highest dilution of serum inhibiting CPE was taken as the end-pont titre.

\section{Detection of antibodies to BVDV}

Antibodies to BVDV were detected by the indirect ELISA, as descrbed by Juntti et al. (1987). In brief, serum antibodies which bound to the wells of microtitre plates coated with BVDV were detected by HRPconjugated monoclonal antibody to bovine IgG.

\section{Results}

Comparison between VNT and ELISA for detection of antibodies to $\mathrm{BCV}$

A total of 91 cattle sera were assayed in VNT and ELISA (Fig. 1). All sera with a VNT titre of 4 or less $(n=26)$ were negative in ELISA. Nine out of 19 sera with a VNT titre of 8 to 16 , and all sera with a VNT titre of 32 or more were positive in ELISA, which was then used throughout this study for detection of antibodies to $\mathrm{BCV}$.

\section{Antibodies to $B V D V$ and $B C V$ during and}

after the episode of winter dysentery

The antibody titres to BCV and BVDV 


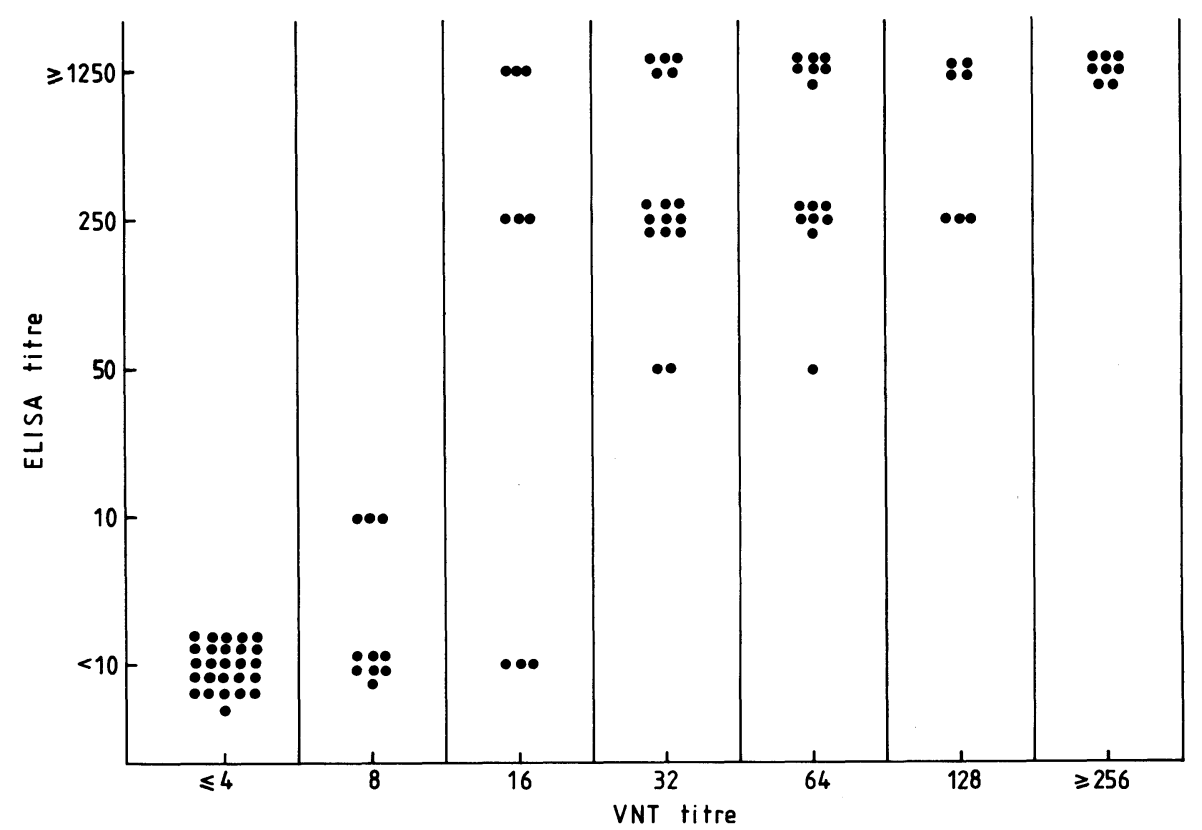

Figure 1. Comparison of antibody titre to bovine coronavirus, detected by ELISA and VNT, in 91 bovine sera.

Table 1. Antibody titres to bovine coronavirus (BCV) and bovine virus diarrhoea virus (BVDV) measured by ELISA in cattle sera during (A) the acute phase of winter dysentery, (B) 3 to 4 weeks later (convalescence phase), and (C) 1 year postinfection.

\begin{tabular}{|c|c|c|c|c|c|c|c|}
\hline \multirow{2}{*}{$\begin{array}{l}\text { Herd } \\
\text { (no.) }\end{array}$} & \multirow{2}{*}{$\begin{array}{c}\text { Main } \\
\text { symptom }\end{array}$} & \multirow{2}{*}{$\begin{array}{l}\text { Number } \\
\text { of cows } \\
\text { tested }\end{array}$} & \multicolumn{3}{|c|}{ Titre to $\mathrm{BCV}$} & \multicolumn{2}{|c|}{ Titre to BVDV } \\
\hline & & & A & B & $\mathrm{C}$ & A & B \\
\hline 1 & D & 7 & $<10$ & $\geq 1250$ & $250-\geq 1250$ & $<10$ & $<10$ \\
\hline 2 & D & 5 & $<10$ & $250-\geq 1250^{a)}$ & n.d. & $<10$ & $<10$ \\
\hline 3 & $\mathrm{D}+\mathrm{R}$ & 7 & $<10$ & $250-\geq 1250$ & $\left.250-\geq 1250^{a}\right)$ & $<10$ & $<10^{\mathrm{a})}$ \\
\hline 4 & $\mathrm{D}+\mathrm{R}$ & 4 & $<10$ & $250-\geq 1250$ & $50-\geq 1250$ & $50-250$ & $50-250$ \\
\hline 5 & $D+R$ & 5 & $<10$ & $250-\geq 1250$ & $250-\geq 1250$ & $<10$ & $<10$ \\
\hline 6 & $\mathrm{D}+\mathrm{R}$ & 5 & $<10$ & $250-\geq 1250$ & $250-\geq 1250^{b)}$ & $<10$ & $<10$ \\
\hline 7 & $\mathrm{D}+\mathrm{R}$ & 4 & $<10$ & $250^{\mathrm{b})}$ & $\left.250-\geq 1250^{c}\right)$ & $<10$ & $<10^{\mathrm{b})}$ \\
\hline 8 & $\mathrm{D}+\mathrm{R}$ & 4 & $<10$ & 250 & $250-\geq 1250$ & $<10$ & $<10$ \\
\hline
\end{tabular}

D: diarrhoea; R: respiratory symptoms; n.d.: not done. a) 4 cows, b) 3 cows, c) 2 cows.

during and after an episode of winter dysentery are listed in Tables 1 and 2. All those animals tested in herds 1 through 8 were seronegative to $\mathrm{BCV}$ (titre $<10$ ) in the acute phase of winter dysentery but seroconverted and showed high titres (250 to
$>1250$ ) both 3 to 4 weeks and 1 year later. The animals showed no rise in antibody titre to BVDV.

In herd no. 9, 2 cows had high antibody titres $(>1250)$ and 3 cows low titres $(<50)$ to $\mathrm{BCV}$ in the acute phase of winter dysen- 
Table 2. Antibody titres to bovine coronavirus (BCV) and bovine virus diarrhoea virus (BVDV) measured by ELISA in sera from dairy herd no. 9 during (A) the acute phase of winter dysentery, (B) 3 to 4 weeks later (convalescence phase), and (C) 1 year postinfection.

\begin{tabular}{rrrcrlrrr}
\hline $\begin{array}{l}\text { Animal } \\
\text { (no.) }\end{array}$ & \multicolumn{3}{c}{ Titre to BCV } & & \multicolumn{3}{c}{ Titre to BVDV } \\
\cline { 2 - 4 } \cline { 7 - 9 } & A & B & C & & A & B & C \\
\hline 1 & 50 & $\geq 1250$ & $\geq 1250$ & & $<10$ & 50 & 250 \\
3 & 50 & $\geq 1250$ & n.d. & & $<10$ & 250 & n.d. \\
12 & $\geq 1250$ & $\geq 1250$ & $\geq 1250$ & & $<10$ & 250 & 250 \\
100 & 10 & $\geq 1250$ & n.d. & & $<10$ & 50 & n.d. \\
113 & $\geq 1250$ & $\geq 1250$ & 250 & & $<10$ & 50 & 50 \\
\hline
\end{tabular}

n.d.: not done.

tery. During the convalescence phase, all animals showed high titres to BCV (> 1250) as well as seroconversion to BVDV (Table 2).

\section{Transfer of BCV antibodies to calves via colostrum}

After the episode of winter dysentery in herd no. 1, sera collected from 6 newborn calves were analysed for presence of antibodies to $\mathrm{BCV}$. Precolostral sera were found to be free from detectable antibodies to BCV. Sera collected from the same calves at the age of 4 to 6 days, i.e., after they received colostrum, showed all antibody titres to BCV. The antibody titre subsequently declined and was usually not detectable in sera from calves older than 5 months (Table 3). All 6 calves were seronegative to $\mathrm{BCV}$ at the age of 7 months.

Prevalence of Swedish heifers with antibodies to $B C V$

Serum antibodies to BCV were detected in $61 \%$ of 549 Swedish heifers examined. The seroreactors to $\mathrm{BCV}$ were almost equally distributed in Sweden.

The herd immunity to $\mathrm{BCV}$, evaluated in 58

Table 3. Antibody titre to bovine coronavirus (BCV) in sera from calves at various ages as measured in ELISA. The calves were born within 5 to 8 months after an episode of winter dysentery in herd no. 1 .

\begin{tabular}{rrrrrrrrrr}
\hline $\begin{array}{c}\text { Calf } \\
\text { (no.) }\end{array}$ & \multicolumn{10}{c}{ Age and titre } \\
\cline { 2 - 10 } & $0-1 \mathrm{db})$ & $4-6 \mathrm{~d}$ & $1 \mathrm{~m}$ & $2 \mathrm{~m}$ & $3 \mathrm{~m}$ & $4 \mathrm{~m}$ & $5 \mathrm{~m}$ & $6 \mathrm{~m}$ & $7 \mathrm{~m}$ \\
\hline 3 & $<10$ & 50 & 50 & 10 & 10 & 10 & $<10$ & $<10$ & $<10$ \\
4 & $<10$ & nd & 250 & 250 & 50 & 10 & 10 & $<10$ & $<10$ \\
5 & $<10$ & $\geq 1250$ & 250 & 50 & 50 & 50 & 10 & 10 & $<10$ \\
7 & $<10$ & 250 & 250 & 50 & 10 & 10 & $<10$ & $<10$ & $<10$ \\
16 & $<10$ & 250 & 250 & 50 & 50 & 10 & 10 & $<10$ & $<10$ \\
19 & $<10$ & $\geq 1250$ & 250 & 250 & 50 & 50 & 50 & 10 & $<10$ \\
\hline
\end{tabular}

b) Precolostral sera.

d: days; m: months; nd: not determined. 


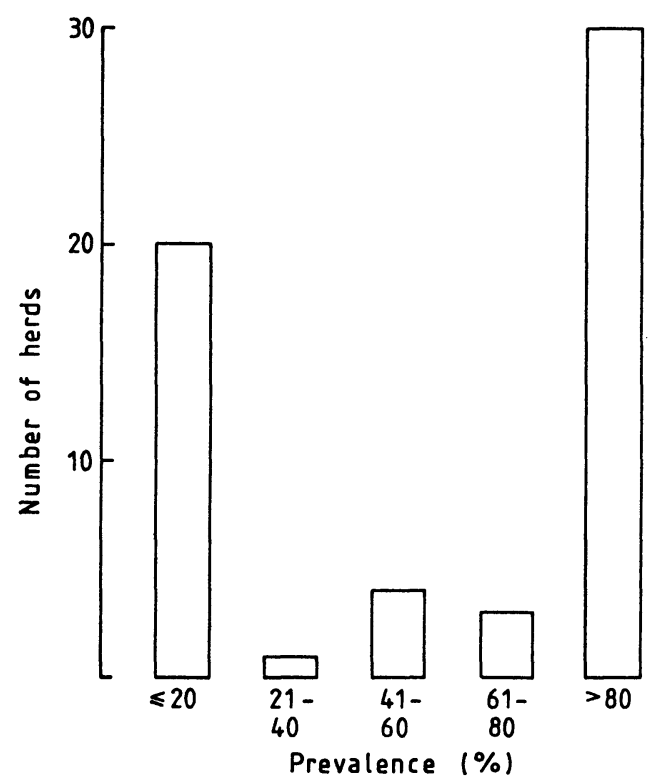

Figure 2. Prevalence of bovine coronavirus seropositive heifers in Swedish herds $(\mathrm{n}=58)$, as moasured in ELISA. Sera from 5 to 14 heifers per herd were examined.

herds, was commonly either high or low (Fig. 2). The prevalence of seroreactors was more than $80 \%$ in 30 of the herds, and $20 \%$ or less in 20 of them.

\section{Discussion}

In the present study, outbreaks of winter dysentery in dairy herds were related to seroconversion to $\mathrm{BCV}$ (Table 1). In addition, we have examined paired sera from Finnish cattle with winter dysentery and found that they also seroconverted to this virus (data not shown). These findings show that $\mathrm{BCV}$ is the aetiological agent of winter dysentery and thereby confirmed the results of other authors (Takahashi et al. 1980, Espinasse et al. 1982, Takahashi et al. 1983, Saif et al. 1988).

In 1 of the herds (no. 9), the winter dysentery was related to seroconversion to BVDV and a rise in antibody titre to $\mathrm{BCV}$ (Table 2). An infection with BVDV is usually subclinical and a previous study indicates a rather slow spread of BVDV among cattle (Barber et al. 1985). In herd no. 9, all tested animals seroconverted to BVDV within a month, indicating that a mixed infection with BCV may increase the spread of BVDV. The cows in this herd were severely affected by the disease and 2 animals died. These findings indicate synergism between $\mathrm{BCV}$ and BVDV. The BVDV, which infects the cells of the immune system, is regarded as being an immunosuppressve agent. A concurrent infection with BVDV may therefore exacerbate the clinical signs caused by other pathogens such as BCV.

The BCV antibody titres remained high 1 year postinfection (Table 1) and were transferred to the offspring via the colostrum. The amount of the passively acquired antibodies subsequently declined and they were usually not detectable in sera from the calves in herd no. 1 when they reached an age over 5 months (Table 3). Also, calves born after the occurrence of the disease in herd no. 3 were seronegative to $\mathrm{BCV}$ at the age of 1 year (data not shown).

Following an episode of winter dysentery in a dairy herd, older seropositive animals will be slaughtered later because of old age or other reasons and they may be replaced with seronegative heifers. The herd immunity to $\mathrm{BCV}$ therefore decreases and the herd will again be susceptible to infection with BCV. This hypothesis is in agreement with the observation that winter dysentery seldom reappears in the same herd more often than every 3 to 4 years (Fox 1980). Winter dysentery only appears to occur in seronegative herds (Table 1). However, in 1 herd (no. 9) $\mathrm{BCV}$ antibodies were present in sera collected from cows during the acute phase of diarrhoea. The serum samples in this herd 
were collected 5 days after the initial signs of infection and it is likely that the animals already had produced antibodies to BCV. The serological survey undertaken in the present study showed that about $35 \%$ of Swedish herds had a low prevalence $(<20 \%)$ of seroreactors to BCV among heifers, indicating that these herds are susceptible to winter dysentery. About $50 \%$ of the herds had a high prevalence $(>80 \%)$ of seroreactors to BCV among heifers and are probably protected against the disease.

Besides being possible aetiological agent of winter dysentery, $\mathrm{BCV}$ is also known to cause enteritis and respiratory disease in calves. Histopathological findings of BCVinduced severe enterocolitis in neonatal calves resemble those of winter dysentery in adult cattle (Van Kruiningen et al. 1987). In a herd with. BCV-associated neonatal diarrhoea, BCV was detected in faeces from adult healthy cattle, particularly during the winter months and at parturition (Collins et al. 1987). In the present study, young calves were usually asymptomatic during the episode of winter dysentery in the adult cattle. More research in this field is obviously needed to achieve a better understanding of $\mathrm{BCV}$ infection and its epidemiology.

In conclusion, the present study provides serological evidence of $\mathrm{BCV}$ being the main causative agent of winter dysentery and shows that about $35 \%$ of Swedish herds are at risk of getting the disease. It was also found that a co-infection with BVDV seems to increase the severity of the disease.

\section{Acknowledgements}

The BCV strain was a kind gift from Professor Anton Mayr, Munich, and the Finnish sera were kindly supplied by dr Erkki Neuvonen. Thanks to Eva Järnberg and Katarina Näslund for skilful laboratory help. Thanks also to Professor Zvonimir Dinter for helpful criticism. This work was supported by grants from the Farmer's Research Council for Information and Development.

\section{References}

Barber DML, Nettleton PF, Herring JA: Disease in a dairy herd associated with the introduction and spread of bovine virus diarrhoea virus. Vet. Rec. 1985, 117, 459-464.

Borgen HC: Mucosal Disease in Dänemark. II. Virologische und serologische Befunde in einem Bestand. (Mucosal disease in Denmark. II. Virological and serological findings in a herd). Nord. Vet.-Med. 1963, 15, 346-356.

El-Ghorr AA, Snodgrass DR, Scott FMM, Campbell I: A serological comparison of bovine coronavirus in adult cattle. Amer. J. vet. Res. 1987, 48, 361-365.

Espinase J, Viso M, Laval A, Aavey M, le Layec $C l$, Blot JP, l'Haridon $R$, Cohen $J$ : Winter dysentery: A coronavirus-like agent in the faeces of beef and dairy cattle with diarrhoea. Vet. Rec. 1982, 110, 385.

Fox FH: Winter dysentery. In: Bovine Medicine \& Surgery, 2nd edition, HE Amstutz (ed.), American Veterinary Publications, Inc., Santa Barbara, California, U.S.A. 1980, Vol. 2, pp. 679-681.

Hedström H, Isaksson A: Epizootic enteritis in cattle in Sweden. Cornell Vet. 1951, 41, 251253.

Jones FS, Little RB: The etiology of infectious diarrhea (winter scours) in cattle. J. exp. Med. 1931, 53, 835-843.

Juntti $N$, Larsson B, Fossum $C$ : The use of monoclonal antibodies in enzyme-linked immunosorbent assays for detection of antibodies to bovine viral diarrhoea virus. J. Vet. Med. B. 1987, 34, 356-363.

Olafson P, MacCallum AD, Fox $H$ : An apparently new transmissible disease of cattle. Cornell Vet. 1946, 36, 205-213.

Reynolds DJ, Debney TG, Hall GA, Thomas LH, Parsons KR: Studies on the relationship between coronaviruses from the intestinal and respiratory tracts of calves. Arch. Virol. 1985, 85, 71-83. 
Saif LJ, Redman $D R$, Brock $K V$, Kohler EM, Heckert $R A$ : Winter dysentery in adult dairy cattle: Detection of coronavirus in the faeces. Vet. Rec. 1988, 123, 300-301.

Takahashi E, Akashi H, Inaba Y: Bovine epizootic diarrhea resembling winter dysentery caused by bovine coronavirus. Japan Agricult. Research Quart. 1983, 17, 185-190.

Takahashi E, Inaba $Y$, Sato K, Ito $Y$, Kurogi $H$, Akashi H, Satoda K, Omori T: Epizootic diarrhoea of adult cattle associated with a coronavirus-like agent. Vet. Microbiol. 1980, 5, 151154.

van Kruiningen HJ, Khairallah LH, Sasseville VG, Wyand MS, Post JE: Calfhood coronavirus enterocolitis: a clue to the etiology of winter dysentery. Vet. Pathol. 1987, 24, 564 567.

\begin{abstract}
Sammanfattning
Bovint coronavirus som orsak till vinterdysenteri: Serologiska bevis.

Sera från kor i 9 besättningar med vinterdysenteri undersöktes på förekomst av antikroppar mot bovint coronavirus (BCV) och bovint virusdiarré virus (BVDV). Kor i 8 av de 9 besättningarna serokonverterade mot BCV, men ej mot BVDV. I den nionde besättningen, där symptomem var grava, serokonverterade djuren både mot $\mathrm{BCV}$ och BVDV. Korna hade höga antikroppstitrar mot BCV ännu 1 år efter genomgången infektion. Antikropparna överfördes från modern till kalven via råmjölken och kvartstod i kalvens serum tills dess att den var ungefär 5 månader gammal.

En serologisk undersökning av 549 kvigor i Sverige visade att $61 \%$ hade antikroppar mot BCV. Prevalensen av antikroppspositiva djur var likartad mellan olika områden i Sverige men var vanligen antingen hög eller låg $i$ enskilda besättningar.

Konklusionen är att BCV är en vanlig orsak till vinterdysenteri och att en saminfektion med BVDV tycks förvärra symptomen.
\end{abstract}

(Received April 2, 1990; accepted May 16, 1990).

Reprints may be requested from: Stefan Alenius, The National Veterinary Institute, P. O. Box 7073, S-750 07 Uppsala, Sweden. 